\title{
PROMISING DIRECTIONS FOR THE LOGISTICS SERVICE PROVIDERS DEVELOPMENT ON THE RUSSIAN MARKET IN TIMES OF RECESSION
}

\author{
Valentina V. Dybskaya ${ }^{1}$, Andrey B. Vinogradov ${ }^{2}$ \\ ${ }^{1,2}$ National Research University Higher School of Economics \\ Moscow, Russia, 20, Myasnitskaya st., 101000 \\ ${ }^{1}+7$ (495) 772-95-90 ext. 22620,vdybskaya@hse.ru \\ 2+7(495) 771-32-58, avinogradov@hse.ru
}

\begin{abstract}
The Russian market of logistics services suffered substantial losses during recent economic recession. Decrease in import from the EU and the USA, reduction of consumer spending within the country, increased borrowing costs led to sharp reduction in the growth rate of the investigated market value. Shortage of the modern infrastructure, fragmentation and imbalance of the Russian logistics market have contributed badly.

This article focuses on identification of the promising strategic development directions for logistics service providers operating on the Russian market. On the basis of literature survey, the authors derive attractive client groups for 3PL operators, priority regions for geographical expansion as well as high-demand logistics and related services. The results of this survey could help logistics agents to define or clarify their market positioning and serve as a basis for further study of specific features in logistics outsourcing development in Russia.
\end{abstract}

Keywords: logistics service, logistics outsourcing, third party logistics, logistics infrastructure

\section{Introduction}

Logistics service outsourcing is gaining more and more popularity in economically developed countries. For instance, in the USA more than $60 \%$ of companies delegate functions like transportation management, warehousing and materials handling to logistics agents (Third Party Logistics Study, 2017). This situation is explained partially by intention to reduce costs because these functions account for the major share of most organizations' logistical costs (Vanhencxthoven et al., 2017). Other typical reasons for logistics outsourcing are improvement in customer service quality (La Londe and Maltz, 1992; McGinnis et al., 1995; Sarel and Zinn, 1992; Persson and Virum, 2001; Stank and Maltz, 1996; Bhatnagar and Viswanathan, 2000; Daugherty et al., 1996; Wong et al., 2000), opportunity for concentration on the company's core competencies and usage of providers' expertise (Sink and Langley, 1997), gaining access to developed distribution networks (Bask, 2001).

In the academic literature, the authors usually separate basic (also called key, essential, traditional, conventional) services, provided by logistics agents, and additional logistics services (value added services) (Grönroos, 2000; Lovelock and Wirtz, 2007). The basic logistics services, referring to the literature, are transportation, freight forwarding, warehousing and materials handling (Van Laarhoven et al., 2000; Berglund et al., 1999; Lundberg and Schönström, 2001; Meier and Andersson, 2003; Bask, 2001; Delfmann et al., 2002). Some authors regard inventory management as basic services (Meier and Andersson, 2003), however considering its coordination rather than operational nature, more complicated realization and increased 3PL provider's qualification requirements, one may proceed, with greater confidence, to include it to the list of value added services. Such services also contain goods assembly, product quality control, pre-sale preparation (co-packing, labelling, repacking, instructions and promotional content stuffing), cross docking, promo materials delivery, returns processing etc. (Atkacuna and Furlan, 2009; Berglund et al., 1999; Lundberg and Schönström, 2001; Bowersox and Closs, 1996; Delfmann et al., 2002; Meier and Andersson, 2003). Individual researchers also regard financial services and consulting as value added services (Meier and Andersson, 2003). Information support services such as tracking of cargo handling and transportation may be considered either as basic services (as they provide core services delivery) or as value added services (Atkacuna and Furlan, 2009).

Types of provided services, in combination with other factors, allow to outline different categories of logistics operators. On the grounds of services complexity and presence of logistics infrastructure, 
academics, traditionally, allocate logistics service providers (LSPs), 3PLs (acting as complex service providers) and 4PL providers (Selviaridis and Spring, 2007).

Today, almost all types of logistics operators, working in the Russian Federation, are going through a difficult time. Evidence of that is a considerable slowdown of the growth rates of the Russian logistics services market value. If in 2011 they constituted 15.8\%; $2012-14.3 \%$; in 2014 they dropped to $1.9 \%$. Positive dynamics in 2015 and 2016 is overriding due to the tariffs growth during the decrease in freight traffic (Simonova, 2016). Commercial road transportation in 2015, in relation to the previous year, decreased by $4.7 \%$; railway transport, during the same period, - by 1.1\% (Simonova, 2016; Mailian, 2016; Ministry of Transport of the Russian Federation, 2016). In 2016 these figures showed a slight increase (by $1.9 \%$ and $0.8 \%$ respectively) but still they are far from the pre-crisis level. Import flows from the EU and North America suffered the sharpest reduction due to sanctions and counter-sanctions. Their amounts in 2015 , compared to the previous year, decreased by $30.5 \%$ and $40.8 \%$ respectively. In 2016 the overall import flow decreased by another $10 \%$ (Simonova, 2016). This state of affairs is quite unfortunate for carriers and providers of freight forwarding services. Logistics agents, providing warehouse storage and material handling, were even more susceptible to economic recession. Thus, according to the agency M.A. Research, share of warehouse services in the total value of the Russian logistics outsourcing in 2015 decreased by $14.8 \%$ regarding 2014 (Simonova, 2016). Logistics operators' share in transactions with high quality warehouse property (A and B class warehouses) during the same period decreased from $14 \%$ in 2014 to $11 \%$ in 2015 (Ryabov, 2017). One of the reasons for this situation was impossibility for increasing tariffs on the services because of the plummeting demand from the remaining clients.

This is not the first time when logistics industry in Russia faces significant challenges, however current economic crisis has its own specifics. Heavy dependence on geopolitical instability; low prices of oil and other Russian export commodities; prohibitive credit rates; intensive outflow of capital from the country; weak investment activity and significant deterioration of investment climate; drop in the industrial output, construction and retail business, rouble devaluation, state control rules modification within the context of a constrained budget are among distinctive features that affect, directly or indirectly, logistics service market, in the opinion of many experts (Simonova, 2016; Galkina, 2016; Guriev, 2015; Strzelecki, 2017).

In the present situation, logistics agents, planning to continue their operations on the Russian market, should decide on the perspectives of their further development. However, researchers have paid undeservedly little attention to the Russian logistics market in general and particularly, in the current economic crisis. Noting the negative impact upon the performance of 3PL operators, a large part of specialists is ignoring strategic opportunities offered to the logistics agents on the Russian market.

Consequently, the subject of the present study is the identification of promising development directions for participants of the Russian logistics outsourcing market in the situation of economic recession.

\section{Methodology}

The present study is based on secondary data analysis, depicting the current state of the Russian logistics services market and its promising development directions.

The Russian market of logistics services does not attract particular attention of foreign researchers, as a consequence, the number of academic papers in the international peer reviewed journals, dedicated to this problem, is very low. For this reason, in order to enrich the research database and increase reliability of its results, the authors considered such sources as the reports of the leading consulting companies and real estate agencies, publications in specialized journals in the Russian language, conference papers dedicated to the logistics infrastructure development in Russia, data from the state statistical bodies and the government of the Russian Federation, the official press releases from the major participants of the domestic logistics outsourcing market in 2013 - 2017.

Search for publications in the Russian and foreign periodicals was carried out in databases like "JSTOR", "Science Direct", "EBSCO”, "ProQuest”, "Emerald”, “eLIBRARY.RU”. The key words and expressions used for the search in question included "logistics outsourcing", "the Russian logistics market", "the Russian logistics outsourcing market", "economic crisis impact on the Russian logistics market development", "Russian warehouse property market". The authors also used official press releases from the major logistics operators on the Russian market.

The authors of scientific publications, forming the base of the current research, used the following research methods: 
- desk study which relies on secondary sources of information analysis (Rosstat's statistics, import and export statistics from the Federal Customs Service, data from industry and professional associations, financial and other statements of market participants, companies' websites, articles, media publications etc.) (Simonova, 2016; Simonova, 2014);

- questionnaires distributed to the market participants (questionnaires messaging in printed and electronic forms, on-line questionnaires usage) (Saddle Creek Logistics Services, 2011; ThirdParty Logistics Study, 2017; McGinnis et al., 1995);

- research of demands for logistics services and logistics infrastructure on the part of the organizations working on the Russian market (Knight Frank, 2016, Ryabov, 2017, Skladman USG, 2017);

- conducting interviews with the representatives of 3PL operators and their clients as well as logistics outsourcing market experts (Soinio et al., 2012; Persson and Virum, 2001; Stank and Maltz, 1996);

- analysis of cases matching the selection criteria (Soinio et al., 2012; Persson and Virum, 2001; Bhatnagar and Viswanathan, 2000).

\section{Main findings and discussion}

To identify promising development directions of the logistics operators on the Russian market, it will be useful to classify them not only by the range of the services but also by specialization of the companies. Such work is represented by (Persson and Virum, 2001) where authors, by a combination of services complexity characteristics and degree of specialization, highlighted four groups of logistics companies: basic logistics operators, specialized logistics operators, advanced logistics network operators and logistics integrators (Fig. 1).

This classification allows not only to evaluate the current state of logistics market (in general or within the country) but also to stress possible strategic development directions of its key players.

Boston Consulting Group (BCG) and Rosbusinessconsulting (RBC) Research estimate that the basis of the Russian logistics outsourcing market is represented by the companies providing transportation services. In 2012 they composed $88 \%$ of market share in monetary terms (Volkov et al., 2014), at the end of 2017 this share must be marginally lower at 87.2\% (Simonova, 2014). The share of warehousing services tends to be substantially lower - it was only $3 \%$ in 2012 and 5.7 in $2017^{1}$. The share of freight forwarding services in recent years has been floating around 6\%. Complex logistics services sector occupies just 8\% of the market (KSK Group, 2017; Dunaev et al., 2016). This sector is represented by 60 Russian and 40 foreign 3PL providers (KSK Group, 2017). According to the Skladman USG study, less than 300 companies in Russia can be considered as logistics agents that provide freight forwarding and temporary storage services. Less than $5 \%$ of them could be attributed as logistics operators which are able to provide full range of logistics services to their clients (Skladman USG, 2015). The share of logistics management services (4PL providers level) in Russia is vanishingly small - 0.6\% (Simonova, 2014).

Thus, one can state that LSPs dominate the Russian market at the moment, and most of them are associated with transportation business. Using Persson and Virum's classification (Fig. 1), it may be noted that the basic logistics operators prevail in the country. The results of the studies, conducted by BCG, indicate that the share of 3PL/4PL sector in Russia is lower than in other countries (Volkov et al., 2014; Third-Party Logistics Study, 2017). Thus, in the USA 24\% of logistics operators' clients use complex service of order management and fulfilment, $23 \%$ of them require reverse logistics service, inventory management is outsourced by $24 \%$ of companies (Third-Party Logistics Study, 2017). According to the research (Baumgarten and Walter, 2000), in the countries of Western Europe the increasing number of logistics operators aim to provide complex services for their clients. This tendency seems to be quite logical as it is more convenient for the companies to receive complex services from one source due to the time, financial and other costs savings (Selviaridis and Spring, 2007).

Comparison between the Russian and foreign markets demonstrates that provision of complex services might become one of key development directions for the domestic logistics operators since it brings added value to the clients and decreases their transaction costs.

\footnotetext{
${ }^{1}$ In the latter case, this share also includes distribution services.
} 


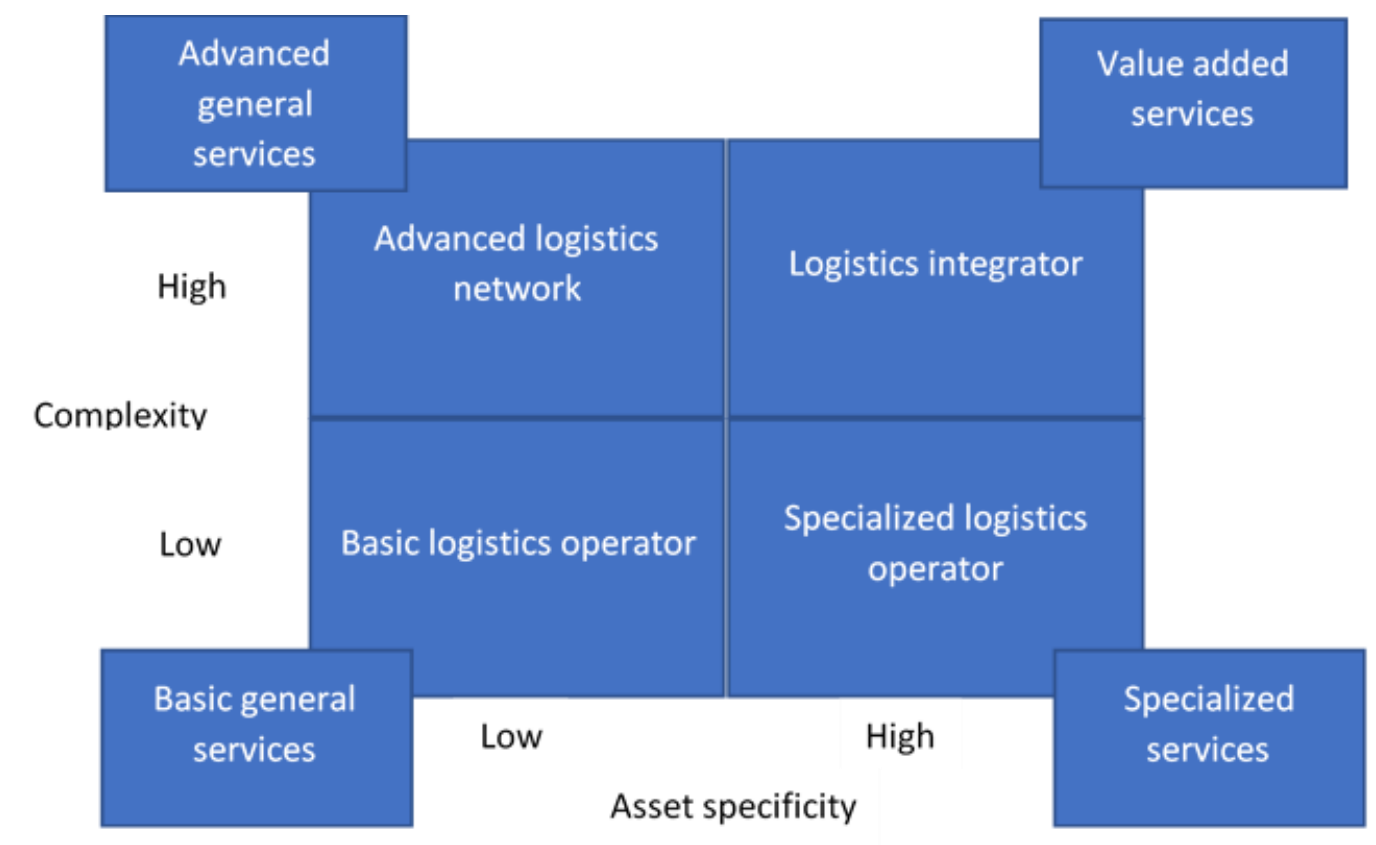

Figure 1. Types of logistics operators (Persson and Virum, 2001)

According to Figure 1, the opportunity for specialization on most promising segments of clients' base should be also taken into account. If Persson and Virum's two-dimensional matrix is enriched with the third dimension "geographical expansion of operator's activity" (with the opposites "localization" "geographical expansion"), on the basis of literature survey, it will be possible to identify the following promising directions for the strategic development of logistics operators on the Russian market:

- provision of logistics services for the retail chains;

- regional expansion (entering the most attractive Russian regions);

- service delivery to small and medium-sized enterprises (SMEs);

- widening the range of logistics services;

- introduction and development of non-logistics services (primarily of the financial nature) accompanying the logistics ones (Fig. 2).

\section{Promising directions of the LSPs strategic development}

\section{on the Russian market}
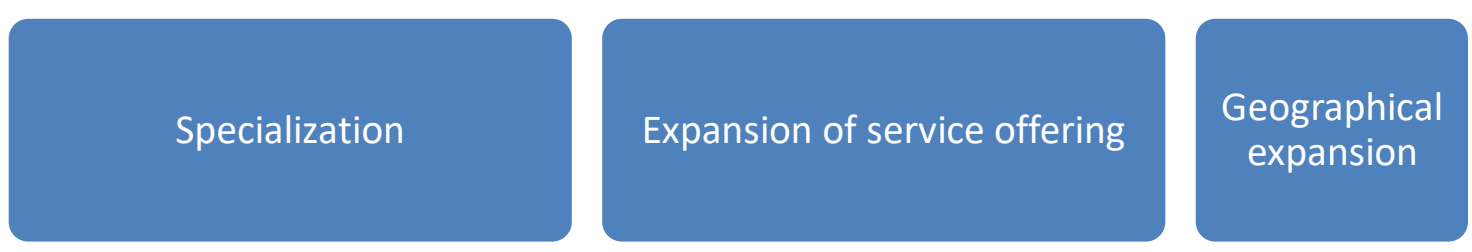

Provision of

the logistics

services for the

retail chains
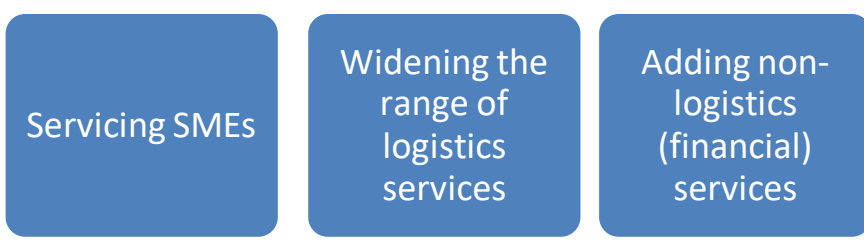

Entering the

most attractive

regions of

Russia

Figure 2. Promising directions of the LSPs strategic development on the Russian market 
Each of the abovementioned perspectives will be carefully reviewed in this article.

The development of an integrated service package for any type of client requires availability of modern highly productive logistics infrastructure. Since warehouse services play an important role in the integrated offer, and the market share of such services is significantly lower than the one of transportation, it makes sense to pay specific attention to the current situation on the Russian market of warehouse property.

The Russian warehouse property market is distinguished by high level of centralization. The research conducted by Jones Lang LaSalle shows that, out of 22 million sq.m of high quality warehouses (A and B category objects), 16 million are located in Moscow, the Moscow Region, Saint Petersburg and Leningrad Oblast (Kholopov, 2017). However, population of the regions in question makes up only 18 per cent of total population of the Russian Federation. The rest of the country's regions account for only 6 million sq.m of high quality storage facilities that are mostly concentrated in several cities with a millionplus population: Ekaterinburg, Novosibirsk, Kazan, Nizhny Novgorod, Rostov-on-Don, Samara, Ufa. Warehouse property overcentralization is stipulated by the regional differences in population density, economic development, capital concentration and it also relates to the specifics of material flows movement (Moscow acts as a distribution centre and the largest transit hub for the entire country).

Moscow warehouse property market is the most developed and has almost 13 million sq.m of high quality storage facilities (59\% of the Russian market in total). Economic recession has significantly affected the capital's warehouse market. Since 2014, new delivery volume of quality warehouse space has been in constant decline. From 2015, the volume of lease and purchase transactions has begun to decrease (Fig. 3).

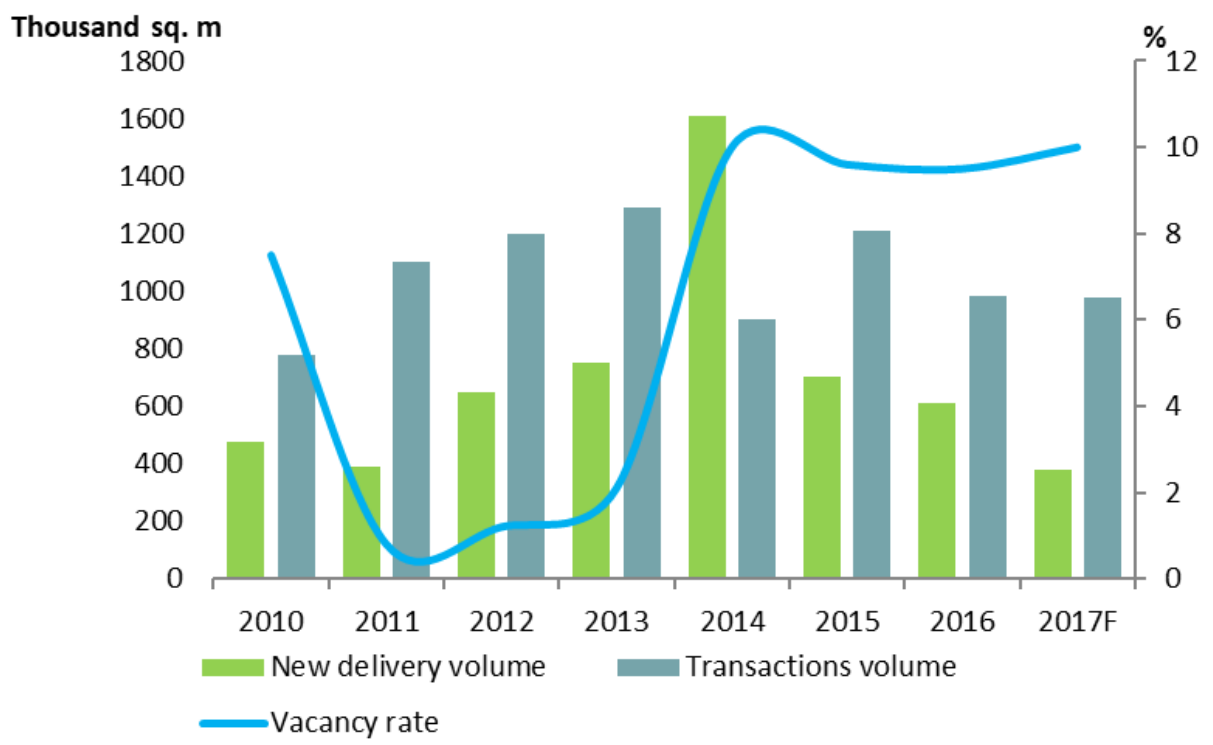

Figure 3. Trends of demand and supply on the Moscow Region warehouse market (Knight Frank, 2017b)

Jones Lang LaSalle research shows that in 2016, 767 th. sq.m (8.6\% less than in 2015) have been placed on the market, while the amount of take-up was 1,186 th. sq.m (9.7\% less than in 2015). In the first half of 2017, quantity of new storage space placed on the market continued to decline (the amount has halved compared to the same period of 2016) (Jones Lang LaSalle, 2017). At the same time, there has been a marked increase in the percentage of vacant space. If before the crisis, vacant share did not exceed 2\%, in 2014 it reached 10\% (Knight Frank, 2017a). According to the company JLL data, vacant warehouse space in the Moscow Region equals 1.47 million sq.m (11.3\% of the total amount) (Jones Lang LaSalle, 2017). The slump in demand for warehouse property led to decrease in the rental rates. Thus, from 2014 to the second quarter of 2017, rental rates on A class warehouses in dollar terms more than halved (fell from 135 to 65 dollar per sq.m / year ${ }^{2}$ ) (Colliers International, 2017b). It should be noted that since the beginning of the economic crisis, accompanied by steep rouble devaluation, there has been a massive renegotiation on warehouse area lease terms as well as rental rates conversion from dollars into roubles. According to the agency Knight Frank data, in the second half of 2015, the market was almost

\footnotetext{
${ }^{2}$ The rates are listed on the triple net basis (excluding VAT, operating expenses and utility payments).
} 
fully nominated in roubles (Kholopov, 2015). Even rental rates denominated in the national currency, in course of the period 2014 - 2017, decreased by $18 \%$ (from 4,650 to 3,800 roubles per sq.m / year) (Colliers International, 2017b).

The economic crisis has also affected the demand pattern for modern warehouses. Thus, based on the company Knight Frank data, the logistics operators' share in the overall volume of lease and purchase transactions in the Moscow Region during the period 2014-2016 reduced from 22\% to 19\% (let alone that in 2008 it was 37\%). As a result of the I-III quarters of 2017, the logistics operators' share in transactions on warehouse property went down to $6 \%$ (Ryabov, 2017). The principal demand on warehouse property is produced by online retailers and wholesale distributors. Their combined share in 2014-2016 was 58$59 \%$ (Ryabov, 2017). Along with that, in 2016, retail chains were key warehouses consumer with a $41 \%$ share (Jones Lang LaSalle, 2016). The same trend was observed in the Russian regions. Thus, according to the company Colliers research, in $2016,63 \%$ of warehouse demand in regions was formed by retail chains (Colliers International, 2017a). Correspondence between the take-up volume of warehouse space and retail turnover is exhibited on Figure 4.

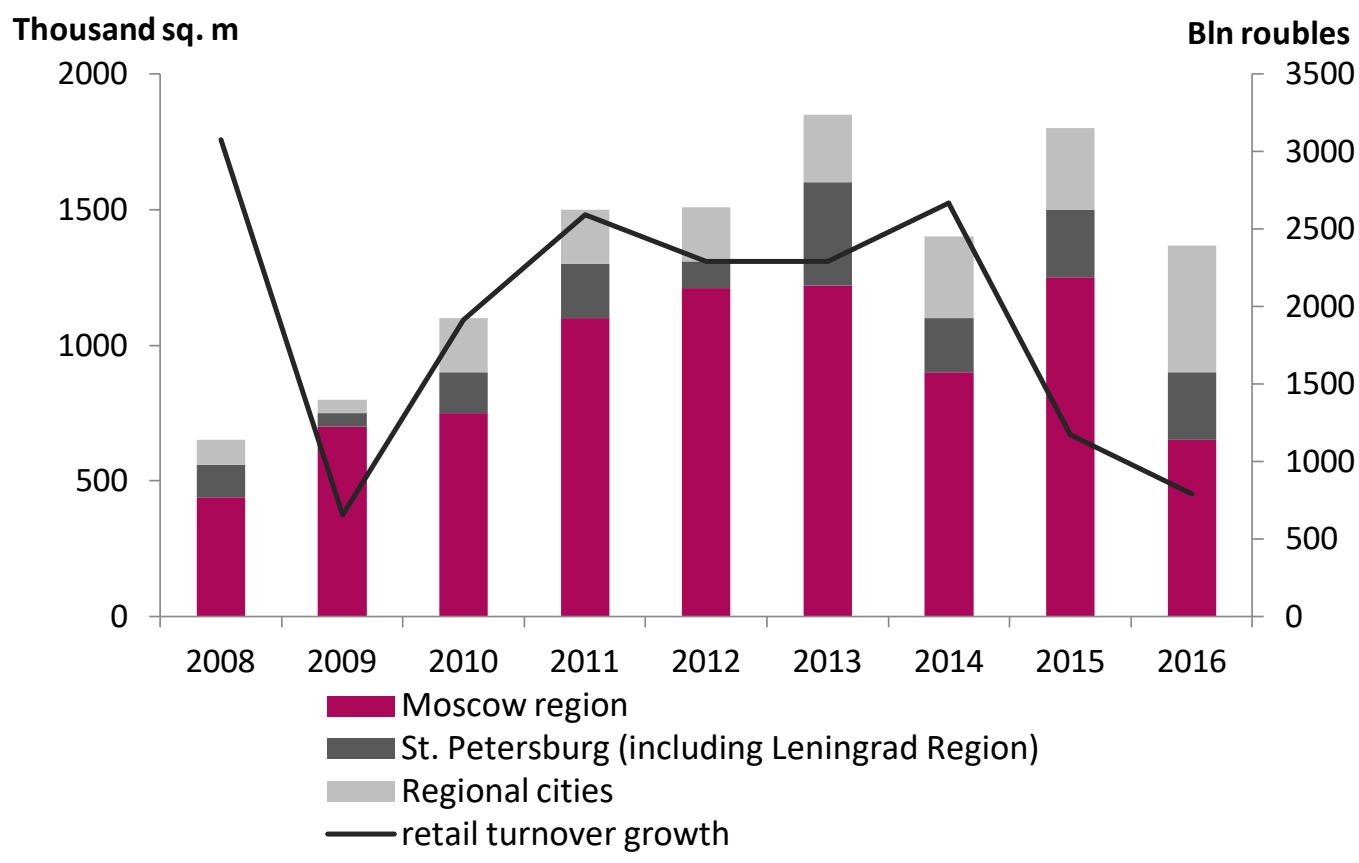

Figure 4. Correspondence between take-up volume of warehouse space and retail turnover (Knight Frank, 2016)

In the first half of 2017, the demand pattern on Moscow Region's warehouse property remained largely unchanged. The first place is occupied by retail business (40\%), the second - wholesalers (24\%), the third - industrial companies with a 15\% share of total transactions volume (Knight Frank, 2017b). These figures show that the retail chains may be considered as essential target consumers for the logistics operators providing services of safe storage and material handling in the Moscow Region and in other Russian regions. However, for encouraging retailer's choice in favour of warehousing activities outsourcing, the logistics operators should provide the following:

- frequent (daily) goods deliveries to stores in small lots in full accordance with the schedule;

- integrated logistics services in various regions of Russia (in case of servicing retail chains of federal scale);

- cartons and eaches picking warehouse services when dealing with huge range of SKUs;

- pre-sale goods preparation at a warehouse;

- competitive service tariffs.

3PL operators' logistics infrastructure (including warehouses) should be appropriate to the specific features of retail business. Need to consider this specificity is proved by the existing developers' construction trend "built-to-suit warehouse", with subsequent sell or rent to clients. According to the company Knight Frank research, it is obvious that the share of "built-to-suit warehouse" in 2016 more than doubled if compared to the previous year (from 29\% to 73\%) (Ryabov, 2017). The remaining 27\% were concentrated on the speculative construction - universal objects aimed at an "average client". 
Taking into account warehouse market saturation in the Moscow Region, logistics operators should consider their development in other regions of Russia. Among the factors, affecting the region's attractiveness for the logistics agent, can be the availability of developed transport infrastructure that is especially important when providing integrated logistics services to clients; relatively high retail business turnover; relatively low level of vacant space in existing warehouse facilities. Vacancy rate might be considered as an indirect indicator of the demand for the logistics services.

These considerations would indicate the following priority regions for the logistics agents development (beyond Moscow and the Moscow Region, Saint Petersburg and Leningrad Oblast):

- Ekaterinburg and Sverdlovsk Region (vacancy rate - 3\%, 2nd place in Russia on retail turnover, excluding Moscow and Saint Petersburg);

- Ufa and the Republic of Bashkortostan (vacancy rate - 5\%, 5th place in Russia on retail turnover);

- Kazan and the Republic of Tatarstan (vacancy level - 6\%, 6th place in Russia on retail turnover) (Kholopov, 2017; Federal State Statistics Service of the Russian Federation, 2017).

The listed cities have favourable locations also in relation to the transportation lines, including the international transport corridor East-West, traversing the Russian territory.

In the longer term, in view of geopolitical factors and Russian strategic orientation on boosting trade with China, considering the intensified usage of Trans-Siberian Railway for international cargo transportation, Krasnoyarsk, Khabarovsk and Vladivostok would be also attractive for the logistics operators. However, at the moment, high quality warehouses in these cities are in short supply.

In general, the experts assess market capacity for warehousing and material handling at $24.3 \mathrm{bln}$. rouble/year. Safe storage accounts for about $50 \%$ of the indicated value. The Skladman USG research indicates that this market has great growth potential (Skladman USG, 2015). However, to realize this potential and survive during the period of economic turbulence, besides offering an attractive "price/service level" ratio and entering the new geographical markets, the logistics agents should navigate through any of the designated routes in Figure 2: to widen the integrated set of services; to increase their specialization level; or to do both.

In the context of service range widening and integration of logistics services, it might be worth considering cross-docking operations in addition to the existing basic services and certain value-added ones (like pre-sale goods preparation) already offered by warehouse operators. Relevance of crossdocking is occasioned by the need of logistics operators' target customers (primarily retail chains) in frequent goods deliveries to stores in small lots combined with the restrictions on the trucks entrance to the million cities. Such restrictions already exist in Moscow and Saint Petersburg (Government of Moscow, 2011; Government of St. Petersburg, 2012) and, apparently, will be gradually introduced in other major cities of the country. Different types of cross-docking have already been put into practice by some Russian market players of wholesale and retail trade (for example, Metro Cash \& Carry and Leroy Merlin) (ECR Russia, 2016; Van Riet, 2017).

The cross-docking advantages for retail business are expressed in reducing store supply lead times; lowering the inventory levels in retailers' distribution centres (Buijs et al., 2014); decreasing costs of storage, order picking and goods delivery to the points of sales (Cattani et al., 2014; Saddle Creek, 2011). Cross-docking is commonly considered as a tool to reduce cost of sales (Stalk et al., 1992) and improve the quality of customer service (Saddle Creek Logistics Services, 2011). Cross-docking may be the effective response to the challenges coming from the unfavourable turn in economic conditions, as a rule, it does not require vigorous investment or vast transformation of existing infrastructure (Saddle Creek Logistics Services, 2011).

Trying to keep up with the clients demand, some logistics service providers have started to roll out the regional cross-docking warehouse networks. Thus, FM Logistic, international logistics company, opened such warehouses in Saint Petersburg, Samara, Rostov-on-Don, Nizhny Novgorod, Volgograd, Ulyanovsk, Krasnodar, Krasnoyarsk, Omsk, Ekaterinburg, Novosibirsk, Khabarovsk and Vladivostok (FM Logistic Russia, 2016).

Specialization of logistics operators may be different depending on the needs of their clients or particular segments of the customer base. SMEs form one of the promising segments of such a base.

Traditionally, logistics agents in the Russian Federation prefer to service major clients with large scale traffic, heavy demand for safe storage, material handling etc. However, in crisis, many big companies from different industries reduced their demand for logistics operators' services, because of overall economic deterioration, reduction in demand from supply chain counterparts, diminution in revenue and profit. LSPs heavy reliance on the limited number of major clients, in some cases, led to decline in sales and reduced the rate of their facilities utilization (in particular, it resulted in the rise of 
vacancy rates at logistics operators' warehouses). Under such circumstances, it seems to be reasonable for logistics operators to pay attention to the previously underestimated clientele - SMEs.

Despite difficult geopolitical and economic conditions over the period of 2014-2016, the number of small and medium-sized enterprises in Russia increased by $14 \%$ and 19\% respectively (Russian SME Resource Centre, 2016). Along with that, there was a strong increase in the sales of medium-sized businesses producing food products, machines and equipment as well as organizations employed in other manufacturing industries (Fig. 5).

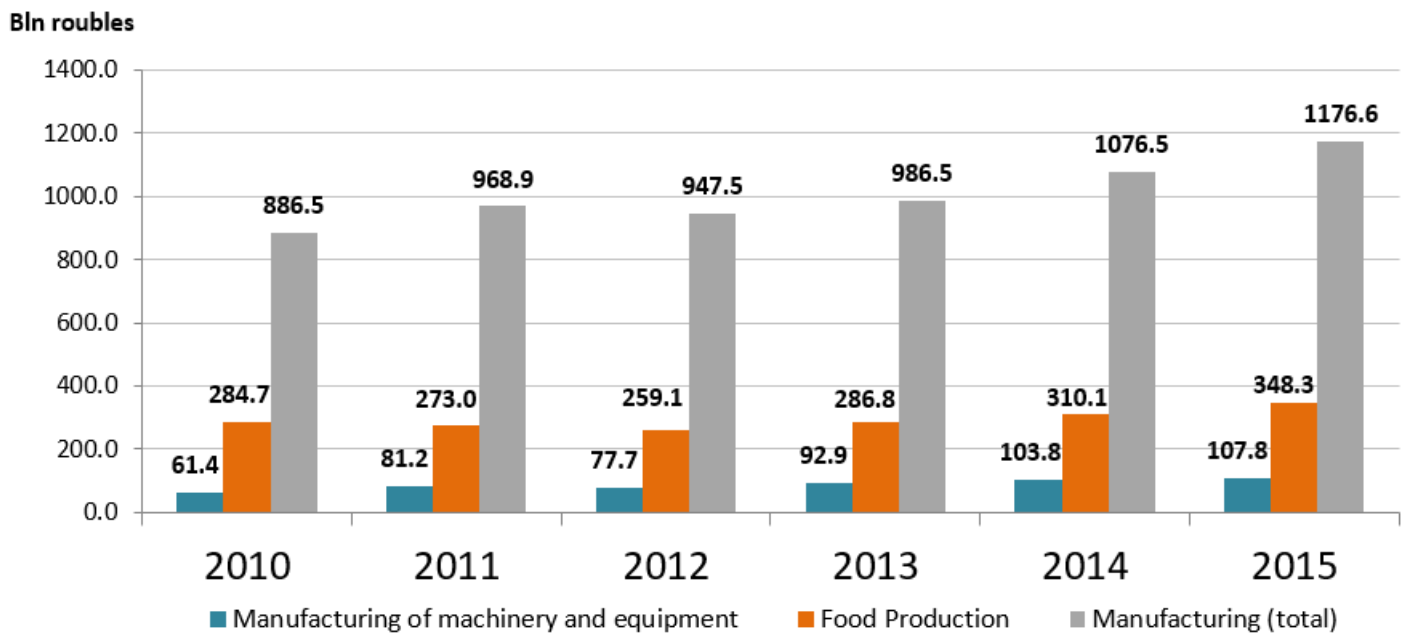

Figure 5. Turnover dynamics of medium-sized businesses in the Russian Federation by the type of economic activity (Federal State Statistics Service of the Russian Federation, 2015)

On June 09, 2016, the Government of the Russian Federation approved the Development Strategy for SMEs in Russia until 2030. Its key objectives include an increase in the SMEs' share in the Russian GDP from current $20 \%$ to $40 \%$, as well as 2.5 times rise in such companies' turnover in comparison with 2014 (from 41.8 to 104.7 trln. roubles) (Government of the Russian Federation, 2016). The document, in particular, embraces measures aimed at facilitating and widening access of small enterprises to the government purchases.

SMEs development will bring rise in demand for the specialized logistics infrastructure. Thus, the Skladman USG research forecasts that by 2030 the demand for "Light Industrial" warehouses (with an area of 100 to 5,000 sq.m and inner height of 6-12 m, specially designed for small and medium-sized businesses) all over the Russian Federation will increase by 3 (conservative scenario) - 6 mln. sq.m (optimistic scenario). In 2016 the aggregated area of small-size warehouses in the Russian Federation was estimated in $5 \mathrm{mln}$. sq.m, of which only $10 \%$ had "prime property" investment grade (analogue of A and $\mathrm{B}$ categories for large-format warehouses). $70 \%$ of the remaining area constitutes a $\mathrm{C}$ class warehouses soviet era facilities, generally, within the former factories. As a comparison, it may be noted that in Germany "Light Industrial" warehouses' total area is $333 \mathrm{mln}$. sq.m. The vacancy rate for "Light Industrial" warehouses in Moscow is 5\%, in other major Russian cities it varies from $2 \%$ to $9 \%$ (Skladman USG, 2017).

High demand for small-size warehouses is a topic of great interest for the commercial property developers. Some of them have already started setting up new-style warehouses. Thus, PNK Group, one of the leaders on warehouse and manufacturing property development market in Russia, announced construction and lease of blocks, with the area starting from 720 sq.m, in Valishchevo industry and logistics park (the Moscow Region), with ready infrastructure and adjacent territory with separate access.

Demand for small warehouses is of interest, also, for 3PL operators since it indirectly demonstrates unmet need of SMEs in the basic logistics services. It seems clear that, in the framework of tight financial resources and high credit rates, investments in own logistics facilities for small and medium-sized businesses are not feasible. The lease of "Light Industrial" warehouses, however, assumes significant investments in acquisition of warehouse equipment, personnel hiring and training, organization of IT support for material handling processes, and, altogether, the development of own logistics competencies. The development of own logistics on the part of SMEs can be justified by the lack of specialized service proposals from the logistics operators, high entry barriers imposed by LSPs, low 
quality of their service as well as excessive tariffs. All these factors are currently relevant for the Russian market. Nevertheless, gradually changing situation can already be observed - major logistics agents start forming special offerings on SMEs servicing. Thus, for example, in 2016 such proposal was developed by FM Logistic, one of the leading players on the Russian logistics services market. The provider offers SMEs simplified access to the integrated services, including international transportation, customs clearance, safe storage, pre-sale goods preparation (packing and co-packing options) as well as goods delivery in Russia (FM Logistic, 2016). The example of major operators is already followed by some of the smaller ones (Dial Group Logistics, 2017). However, in order to be successful and competitive, the logistics operators' service offering for SMEs should take into account specific characteristics of this sector and its dissimilarity from the one of large companies. Those features and dissimilarities include the following:

- lower level of available funding (Wagner and Franklin, 2008);

- longer cash-to-cash cycle;

- commitment to short-term financial results;

- lack of time for management to implement changes (Brau et al., 2007);

- dependence on core clients and their ways of interaction in the supply chains (Arend and Wisner, 2005; Quayle, 2003);

- lack of knowledge or resources for effective implementation of key logistics functions (Soinio et al., 2012).

This list may be added with a necessity of flexible logistics service and fixed costs reduction in the times of crisis, making customer demand even more volatile and harder to forecast. In practice, for instance, it leads to unacceptability of long-term reservation of warehouse space and shift to the tariffs in line with actual capacity utilization.

The presented features explain the need of some SMEs not only in the basic logistic services of the operational level but also in logistics operation planning and consulting services on supply chain management issues (Soinio et al., 2012).

Because of the existing working capital shortage, financing of inventories or factoring may be of great interest for lots of SMEs. While a bank and a client negotiate a loan, client's goods are located at the logistics provider's warehouse. In this case LSP can supply the bank with credible information on the current status of the client's inventory. Thus, having the latest information about the client's material flow, the logistics operator reduces the bank's risk and plays an important role in ensuring reliability of this financing scheme. Factoring supposes even more active participation of logistics operator in providing financial services to the client. This scheme assumes that SME (supplier) sells goods to another company (customer) and 3PL operator provides the supplier with the basic logistics services (including goods delivery to the client) as well as with the value added ones. Upon receiving information about the customer order from the supplier, the logistics operator pays the supplier for the goods (fully, except for its commission, or partially - in accordance with the agreement between the parties). Then, the operator delivers goods to the customer and receives money for the shipment. Therefore, in this scheme, the logistics agent performs not only its traditional functions but also acts as a factor. This has the following obvious benefits for SME: reduction in cash-to-cash cycle and, consequently, decrease in the need for expensive working capital. Factoring for SMEs can be cheaper than traditional bank loans, since banks often consider SMEs as low credit score borrowers. At the same time, bank's credit rate for large-scale and long-standing 3PL operator to provide factoring service may be lower than for SME. In case logistics service provider's credibility is higher than the customer's one, SME becomes a winner, too. The reason behind that is the difference in credit rates which directly affects the customer's inventory holding costs (Chen and Cai, 2011).

Logistics operator in this scheme increases its revenue by providing financial services in addition to the basic ones (Chen and Cai, 2011). Besides, 3PL operator, providing these services, becomes more attractive for the vendors and the customers in the supply chains. This results in growing market share of such LSP (Cao and Zhang, 2013). Of course, there are several risks: credit, moral, legal, administrative (Yan and Suo, 2013) that need to be considered by logistics operators when they assess the feasibility of financial services provision.

Inventory in-transit financing is already available on the markets of the economically developed countries as well as some of the developing ones. Thus, for example, such services have been well known and widely used in China for almost two decades. On a national scale this business started in 1999, when CMST, the provider of logistics services, joined forces with several commercial banks. At the moment, the number of SMEs, using logistics operators' financial services, is constantly growing. Potential of this market arouses interest on the part of both practitioners and academics (Liu et al., 2015). 
Despite the novelty of such services for the Russian market, the first logistics operator, offering an opportunity for inventory financing and factoring to its clients beyond the traditional service, has already appeared. These services are proposed by IML in partnership with "RFI Bank" JSC which holds the controlling stake in the logistics service provider (Banki.ru, 2017).

\section{Conclusions}

Currently basic logistics operators dominate the Russian market of logistics services. Carriers and freight forwarders constitute the major part of such operators. The development of the logistics outsourcing market is constrained by a lack of high quality logistics infrastructure, unfavourable economic situation, difficult geopolitical environment, decrease in foreign trade turnover with the European Union and the USA. To secure and reinforce their businesses under current conditions, LSPs may choose such directions of strategic development as specialization on the needs of the most promising groups of clients, enlargement of the service offerings and geographical expansion. Retail chains are among the most promising clients for logistics operators in Russia. Retailers, developing the chains of discount stores, are of utmost interest since this format demonstrates outstripping growth in times of economic recession and population's disposable income reduction. Permanently high share of the retailers among the warehouse property leasers is the telltale sign of their unmet demand for the logistics services.

SMEs form another promising segment of the customer base for the logistics operators to pay attention to. The state program to support the development of small and medium-sized businesses is aimed at doubling their contribution into the Russia's GDP that will lead to the comparable growth of SMEs' demand in logistics services. Acute shortage of the appropriate logistics infrastructure - "Light Industrial" warehouses is another factor explaining the demand for the logistics providers' services on the part of SMEs.

Focus on retail chains and SMEs requires logistics operators to develop not only transportation services but also warehousing ones that are currently lagging behind. These services embrace loading and unloading of the trucks, receiving and inspection, sorting of goods, safe storage, order picking at different levels (including eaches), packing and co-packing, pre-sale preparation and palletizing. Having a warehouse, logistics operator can raise its attractiveness for the clients by providing them with crossdocking service in the classical form as well as with some degree of consolidation. Another way to enlarge service offering involves logistics operations planning and SCM consulting services that are of particular relevance for SMEs.

Besides the traditional logistics package, additional financial services are gaining more and more popularity. Strategic partnership with banks significantly increases 3PL operators' capabilities, allowing to provide inventory financing and factoring to their clients. These financial services are highly relevant under current economic conditions.

Along with the service range enlargement and focusing on the needs of the listed types of clients, LSPs could also consider entering not only Moscow and Saint Petersburg but also such promising geographical markets as Yekaterinburg and Sverdlovsk Region; Ufa and the Republic of Bashkortostan; Kazan and the Republic of Tatarstan.

The results of the conducted research produce practical benefit for the managers of 3PL operators by helping them to identify promising areas for further development in unstable economic environment. The obtained results are also highly relevant for academics, as they provide starting point for further research of the Russian logistics outsourcing market. Potential areas for further research include examination of the demand for the logistics services created by internet retailers and omnichannel companies; analysis of the development prospects for the logistics management outsourcing in Russia ${ }^{3}$; evaluation of the relative SMEs' demand for operational and managerial logistics services; identification of priority areas for the strategic development based on the type of the logistics operator.

\section{Acknowledgements}

This article is an output of a research project "Research of the major directions for the logistics service providers development under the conditions of adaptation to the changing economic reality in Russia" as the part of the Research Program of the Faculty of Business and Management at National Research University Higher School of Economics.

\footnotetext{
${ }^{3}$ Logistics management outsourcing embraces the cases of LSP operating the client's logistics infrastructure (e.g. the client's warehouse).
} 


\section{References}

1. Arend, R., Wisner, J. (2005) Small business and supply chain management: is there a fit? Journal of Business Venturing, 20, 403-436.

2. Atkacuna, I. and Furlan, K. (2009) Value-Added Services in Third-Party Logistics: A study from the TPL providers' perspective about value-added service development, driving forces and barriers (Master's Thesis). Jönköping: Jönköping University.

3. Bask, A.H. (2001) Relationships between 3PL providers and members of supply chains - a strategic perspective. Journal of Business and Industrial Marketing, 16 (6), 470-86.

4. Baumgarten, H., Walter, S. (2000) Trends und Strategien in der Logistik 2000+. Berlin: TU Berlin.

5. Berglund, M., van Laarhoven, P., Sharman, G., and Wandel, S. (1999) Third-Party Logistics: Is There a Future? The International Journal of Logistics Management, 10 (1), 59-69.

6. Bhatnagar, R. and Viswanathan, S. (2000) Re-engineering global supply chains: alliances between manufacturing and global logistics service providers. International Journal of Physical Distribution \& Logistics Management, 30 (1), 13-34.

7. Bowersox, D.J. and Closs, D.J. (1996) Logistical Management: The Integrated Supply Chain Process. New York: The McGraw-Hill Companies, Inc.

8. Brau, J.C., Fawcett, S.E., Morgan L. (2007) An empirical analysis of the financial impact of supply chain management on small firms. The Journal of Entrepreneurial Finance, 12 (1), 55-82.

9. Buijs, P., Vis, I.F., Carlo, H.J. (2014) Synchronization in cross-docking networks: a research classification and framework. European Journal of Operational Research, 239 (3), 593-608.

10. Cao, W., Zhang, Y. (2013) Study on the advance payment rate of advance-payment collection business based on logistics financial. Creative Education, 3, 43-46.

11. Cattani, K.D., Souza, G.C., Ye, S. (2014) Shelf loathing: cross docking at an online retailer. Production and Operations Management, 23 (5), 893-906.

12. Chen, X., Cai, G. (2011) Joint logistics and financial services by a 3PL firm. European Journal of Operational Research, 214(3), 579-587.

13. Colliers International (2017a) Warehouse property of Russia. Results of 2016 (in Russian). Warehouse and equipment, 3 (161), 10-13.

14. Daugherty, P.J., Stank, T.P. and Rogers, D.S. (1996) Third party logistics service providers: purchaser's perceptions. International Journal of Purchasing and Materials Management, 32 (2), 23.

15. Delfmann, W., Albers, S., and Gehring, M. (2002) The impact of electronic commerce on logistics service providers. International Journal of Physical Distribution \& Logistics Management, 32(3), 203-222.

16. Dunaev, O., Demin, V., Ezhov, D., Kulakova T., Nesterova, D. (2016) Trans-Euroasian logistics platform: practice, products and markets (in Russian). Moscow: Chamber of Commerce and Industry of the Russian Federation.

17. Federal State Statistics Service of the Russian Federation (2015) Statistical compendium "Small and medium entrepreneurship in Russia. 2015" (in Russian). Moscow: Rosstat.

18. FM Logistic (2016) FM Logistic Russia official corporate presentation. Moscow: FM Logistic.

19. Galkina, Yu. (2016) Trends of the development of the logistics service market in Russia (in Russian). Logistics systems in global economy, 6, 427-430.

20. Grönroos, C. (2000) Service management and marketing: a customer relationship approach (2 ${ }^{\text {nd }}$ ed.). Chichester, UK: John Wiley \& Sons, Ltd.

21. Guriev, S. (2015) Political Origins and Implications of the Economic Crisis in Russia. In: Putin's Russia: How it Rose, How it is Maintained, and How it Might End, ed. Leon Aron. Washington D.C.: American Enterprise Institute, pp. 8-35.

22. Kholopov, V. (2017) Review of the Russian market of warehouse property. New formats (in Russian). Moscow: Jones Lang LaSalle.

23. Kholopov, V. (2015) Time will tell. In: Proceedings of the XI annual warehouse conference (in Russian), Moscow, September 2015. Moscow: Knight Frank, 24.

24. La Londe, B. and Maltz, A.B. (1992) Some propositions about outsourcing the logistics function. International Journal of Logistics Management, 3 (1), 1-11.

25. Liu, X., Zhou, L., Wu, Y.-C.J. (2015) Supply Chain Finance in China: Business Innovation and Theory Development. Sustainability, 2015, 7, 14689-14709.

26. Lovelock, C. H. and Wirtz, J. (2007) Services Marketing: People, Technology and Strategy (6 ${ }^{\text {th }}$ ed.). Upper Saddle River, New Jersey: Prentice Hall.

27. Lundberg, H. and Schönström, M. (2001) Segmentation of the Third Party Logistics Market. Based on Logistics Requirements. Thesis. No 2001:25. Gothenburg: Gothenburg University. 
28. McGinnis, M.A., Kochunny, C.M. and Ackerman, K.B. (1995) Third party logistics choice. International Journal of Logistics Management, 6 (2), 93-101.

29. Meier, T. and Andersson, D. (2003) The Swedish TPL Industry - An Overview From the End of the 1990s to 2000. In: D. Andersson, H.C. Dreyer, A. Halldorsson, M. Jahre, L. Ojala, T. Skjott-Larsen and Virum, H (Eds.), Third Party Logistics - A Nordic Research Approach, Turku, Finland: Turku School of Economics and Business Administration, pp. 25-46.

30. Ministry of Transport of the Russian Federation. (2016) Informational-statistical bulletin «Transport of Russia» January-December 2015 (in Russian). Moscow: Ministry of Transport of the Russian Federation.

31. Persson, G. and Virum, H. (2001) Growth strategies for logistics service providers: a case study. International Journal of Logistics Management, 12 (1), 53-64.

32. Quayle, M. (2003) A study of supply chain management practice in UK industrial SMEs. Supply chain management: An International Journal, 8 (1), 79-86.

33. Ryabov, V. (2017) Between West and East. In: Proceedings of the XIII annual warehouse conference (in Russian), Moscow, September 2017. Moscow: Knight Frank.

34. Sarel, D. and Zinn, W. (1992) Customer and non-customer perceptions of third party services: are they similar? International Journal of Logistics Management, 3 (1), 12-22.

35. Selviaridis, K. and Spring, M. (2007) Third party logistics: a literature review and research agenda. The International Journal of Logistics Management, 18 (1), 125-150.

36. Simonova, L. (2016) Market of logistics outsourcing. Results of 2015-2016 and forecast till 2019 (in Russian). Moscow: M.A. Research.

37. Simonova, L. (2014) Market of transport-logistics services in 2013-2014 and its forecast till 2017 (in Russian). Moscow: RBC Research.

38. Sink, H.L. and Langley, C.J. (1997) A managerial framework for the acquisition of third-party logistics services. Journal of Business Logistics, 18 (2), 163-89.

39. Skladman USG (2017) Review of the market of light industrial and multi-let light industrial warehouses (in Russian). Moscow: Skladman USG.

40. Soinio, J., Tanskanen, K., Finne, M. (2012) How logistics-service providers can develop value-added services for SMEs: A dyadic perspective. International Journal of Logistics Management, 23 (1), 3149.

41. Stalk, G., Evans, P., Shulman L.E. (1992) Competing on capabilities: the new rules of corporate strategy. Harvard Business Review, 63 (2), 57-69.

42. Stank, T.P. and Maltz, A.B. (1996) Some propositions on third party choice: domestic vs. international logistics providers. Journal of Marketing: Theory and Practice, 4 (2), 45-54.

43. Strzelecki, J. Painful adaptation: the social consequences of the crisis in Russia. Warsaw: Centre for Eastern Studies, 2017.

44. Vanhencxthoven, M., Monahan, S., Zimmerman, M., Ward, J., Sonthalia, B. (2017) The 28th Annual Council of Supply Chain Management Professionals (CSCMP) 2017 State of Logistics Report. Accelerating into uncertainty. Lombard, US: CSCMP.

45. Van Laarhoven, P., Berglund, M., and Peters, M. (2000) Third-party logistics in Europe - five years later. International Journal of Physical Distribution \& Logistics Management, 30(5), 425-442.

46. Volkov, M., Dunaev, O., Ezhov, D., Pamoukhin, V., Perapechka, S., Roubin, G., Timofeev, A. (2014) Logistics in Russia: new ways of unfolding its potential (in Russian). Moscow: The Boston Consulting Group.

47. Wagner, M., Franklin, J. (2008) Why LSPs don't leverage innovations. CSCMP's Supply Chain Quarterly, 4, 67-71.

48. Wong, Y.Y., Maher, T.E., Nicholson, J.D. and Gurney, N.P. (2000) Strategic alliances in logistics outsourcing. Asia Pacific Journal of Marketing and Logistics, 12 (4), 3-21.

Web sources:

49. Banki.ru (2017) Shareholders of RFI Bank have consolidated the stake in the logistics company IML, from: http://www.banki.ru/news/lenta/?id=9667206 (access: November 2017)

50. Colliers International (2017b) Moscow. Warehouse property. H1 2017, from: http://www.colliers.com/-/media/files/emea/russia/research/2017/h1_industrial_rus.pdf?la=ru-RU (access: November 2017)

51. Dial Group Logistics (2017) Storage services for small and medium business, from: http://dglsklad.ru/articles/otvetstvennoe-khranenie-dlya-malogo-i-srednego-biznesa.html (access: November 2017) 
52. ECR Russia (2016) ECR Insight, from: http://ecr-all.org/events/ecr_2016.pdf (access: November 2017)

53. Federal State Statistics Service of the Russian Federation (2017) Retail turnover, from: http://www.gks.ru/wps/wcm/connect/rosstat_main/rosstat/ru/statistics/enterprise/retail/\# (access: July 2017)

54. FM Logistic (2016) FM Logistic offers an integrated solution for small and medium enterprises, from: http://www.fmlogistic.ru/eng-gb/Medias/News/FM-Logistic-offers-an-integrated-solution-forsmall-and-medium-enterprises (access: November 2017)

55. Government of Moscow (2011) Government regulations on the restriction of lories circulation in Moscow and on the declaration of invalidity of certain legal acts of the Government of Moscow. 22 August 2011 No. 379-PP, from: https://www.mos.ru/upload/photobank/common/upload/379PP_22_avgusta_2011_g.pdf (access: November 2017)

56. Government of St. Petersburg (2012) Regulations of March 27, 2012 on the procedure of realization of temporary restrictions or cessation of traffic on the regional roads in St. Petersburg, from: http://gov.spb.ru/law?print\&nd=822400595 (access: November 2017)

57. Government of the Russian Federation (2016) Government order of June 2, 2016 No. 1083-r On the strategy of development of small and medium entrepreneurship in the Russian Federation till 2030 and roadmap of its implementation, from:

http://static.government.ru/media/files/jFDd9wbAbApxgEiHNaXHveytq7hfPO96.pdf (access: November 2017)

58. Jones Lang LaSalle (2016) Review of the warehouse market of Moscow and Moscow region, 4th quarter of 2016, from: http://www.jll.ru/russia/ru-ru/исследования/233/обзор-рынка-складскойнедвижимости-москвы-мо-4-квартал-2016-года (access: November 2017)

59. Jones Lang LaSalle (2017) Review of the warehouse market of Moscow and Moscow region, 2d quarter of 2017, from: http://www.jll.ru/russia/ru-ru/исследования/261/обзор-рынка-складскойнедвижимости-москвы-мо-2-квартал-2017 (access: November 2017)

60. Knight Frank (2016) Q1 2017 Warehouse property of Russia, from: http://content.knightfrank.com/research/856/documents/ru/warehouse-market-reportregionsrus-short4038.pdf (access: November 2017)

61. Knight Frank (2017a) Q1 2017 Warehouse market report Moscow, from: http://content.knightfrank.com/research/596/documents/en/moscow-warehouses-market-4684.pdf (access: November 2017)

62. Knight Frank (2017b) H1 2017 Warehouse market report Moscow, from: http://content.knightfrank.com/research/596/documents/en/moscow-warehouse-market-h1-20174918.pdf (access: November 2017)

63. KSK Group (2017) Complex logistics services. In: KSK group industrial bulletin. Moscow: KSK Group, 3, p. 7, from:

https://kskgroup.ru/wp-content/uploads/2016/11/860bbfd1192b52fc0e84c069f8655726.pdf (access: November 2017)

64. Mailian, A. (2016) Market of transport and logistics services. Novainfo, 46 (4), from: http://novainfo.ru/article/6381 (access: November 2017)

65. PNK Group (2017) PNK Group brings a new format to the market - an industrial townhouse, from: http://www.pnkgroup.ru/en/events/ (access: November 2017)

66. Russian SME Resource Center (2016) The amount of legal entities and private individuals registered in the United Register of SMEs as of August 1, 2016, from: https://rcsme.ru/index.php/ru/statistics (access: November 2017)

67. Saddle Creek Logistics Services (2011) 2011 Cross-docking trends report, from: https://www.sclogistics.com/whitepapers/cross-docking-trends-report-2011 (access: November 2017)

68. Skladman USG (2015) Review of the current state of the storage market, from: http://skladman.com/ru/analitics\#close (access: November 2017)

69. Third-Party Logistics Study (2017) 2017 21st Annual Third-Party Logistics Study: The State of Logistics Outsourcing, from: http://www.3plstudy.com/3pldownloads.php (access: November 2017)

70. Van Riet, C. (2017) Supply chain evolution in a crisis: Case studies from Russia. CSCMP'S Supply Chain Quarterly, Quarter 1 2017, from: http://www.supplychainquarterly.com/topics/Logistics/20170301supply-chain-evolution-in-a-crisis-case-studies-from-russia (access: November 2017)

71. Yan, Y. and Suo, B. (2013) Risks analysis of logistics financial business based on evidential Bayesian network. Mathematical Problems in Engineering, 2013, from:

https://www.hindawi.com/journals/mpe/2013/785218 (access: November 2017) 